\section{Importance of coryneform bacteria in infective endocarditis}

\section{Alexander von Graevenitz \\ University of Zürich, Switzerland}

Coryneform bacteria have been defined as non-sporing Gram-positive rods with an irregular outline. ${ }^{1}$ Almost all can be grown aerobically and assigned to the class Actinobacteria which are characterized by a high guaninecytosine content $(>50 \%)$ and specific $16 \mathrm{~S}$ rDNA signature nucleotides. ${ }^{2}$ Some of the genera in this class are environmental bacteria but some (e.g., Actinomyces, Brevibacterium, Corynebacterium, Dermabacter, Propionibacterium, and Rothia) belong to the human microbiome and have also been reported as agents of human and animal disease. Coryneform genera and species have been either confirmed or newly outlined since the 1990s when biochemical and molecular tests (PCR, 16S rDNA sequencing) were undertaken on a large scale. ${ }^{3}$

Coryneform endocarditis is rare. In an international study on infective endocarditis coryneforms ${ }^{4}$ although not specifically mentioned, probably figured among the 4 to $5 \%$ of causative microorganisms other than staphylococci, streptococci, enterococci, HACEK, fungi, and those causing polymicrobial or culturenegative infections. By now, species of Actinomyces, Arcanobacterium, Arthrobacter, Brevibacterium, Cellulosimicrobium, Cellulomonas, Corynebacterium, Gardnerella, Propionibacterium, and Rothia have been reported as agents of infective endocarditis, albeit for most of them the number of cases has been so small as to exclude an evaluation of pertinent features of the disease and its treatment. This is even true for the genera Actinomyces and Rothia, ${ }^{5,6}$ since reported cases of individual species are not numerous enough yet for a satisfactory analysis. At this time, the only exceptions are cases due to Corynebacterium diphtheriae, C. pseudodiphtheriticum, C. striatum, and Propionibacterium acnes. Cases reported earlier as coryneform or diphtheroid endocarditis cannot be included in evaluations since they lack species diagnoses.

A 2007 review article has listed risk factors and outcomes of infective endocarditis due to various species of the genus Corynebacterium. ${ }^{8}$ Aortic and mitral valves were affected in most instances. Non-toxigenic strains of $C$. diphtheriae have caused endocarditis in homeless and HIV-positive individuals as well as in drug addicts who transmitted the organisms through needle sharing as proven by ribotyping. ${ }^{9}$ Treatment with penicillin alone or in combination with an aminoglycoside was mostly successful, in contrast to cases due to toxigenic strains. ${ }^{8,10}$
Toxigenic strains of different clonal groups have exhibited an aggregative-adhering pattern in HEp-2 cells. ${ }^{11}$ While strains of $C$. pseudodiphtheriticum affected males and those with prosthetic valves more frequently and showed higher mortality than non-toxigenic strains of $C$. diphtheriae,$^{12}$ strains of $C$. striatum causing endocarditis were frequently nosocomial and multiply antibiotic-resistant but the majority of patients survived under appropriate treatment. ${ }^{8,13}$

$P$. acnes is probably underestimated as an agent of infective endocarditis. While the percentage of isolates from blood cultures that can be attributed to endocarditis is very small - most isolates are skin contaminants approximately 50 cases have been reported in the literature. ${ }^{14}$ Males and patients with prosthetic valves were affected predominantly; and complications such as myocardial abscesses and valvular insufficiency were frequent. ${ }^{15}$ In spite of treatment with antibiotics that were effective in vitro (penicillin alone or with an aminoglycoside) ci. $75 \%$ of the patients had to undergo surgery. Interestingly, only $62 \%$ showed positive blood cultures, ${ }^{15}$ in the rest, the diagnosis was made by histopathology of the excised valves. ${ }^{16}$

It is to be hoped that species identification and susceptibility testing of microorganisms in cases of coryneform endocarditis will lead to characterization of more species-specific features.

\section{References}

1. Rogosa M, Cummins CS, Lelliott RA, Keddie RM. Coryneform group of bacteria. In: Buchanan RE, Gibbons NE, eds. Bergey's manual of determinative bacteriology. 8th ed. Baltimore: Williams \& Wilkins; 1974. pp. 599-602.

2. Stackebrandt E, Rainey FA, Ward-Rainey NL. Proposal for a new hierarchic classification system, Actinobacteria classis nov. Int J System Bacteriol 1997;47:479-91.

3. Funke G, Bernard KA. Coryneform Grampositive rods. In: Versalovic J, ed. Manual of clinical microbiology. 10th ed. Washington D.C.: American Society for Microbiology; 2011. pp. 413-442.

4. Murdoch DR, Corey GR, Hoen B, et al. Clinical presentation, etiology and outcome of infective endocarditis in the 21st century: the international collaboration on endocarditis-prospective cohort study. Arch Intern Med 2009;169:463-73.

5. Kottam A, Kaur R, Bhandare D, et al. Actinomycotic endocarditis of the Eustachian valve: a rare case and review of the literature. Tex Heart Inst J 2015;42:449 .
Correspondence: Alexander von Graevenitz, University of Zürich, Nidelbadstrasse $10, \mathrm{CH}$ 8802 Kilchberg, Switzerland.

Tel.: +41.44.715.3274.

E-mail: avg@imm.uzh.ch

Key words: Infective endocarditis; coryneforms; corynebacterium; propionibacterium.

Conflict of interest: the author reports no conflict of interest.

Received for publication: 7 July 2015 .

Accepted for publication: 21 July 2015.

This work is licensed under a Creative Commons Attribution NonCommercial 3.0 License (CC BYNC 3.0).

(C) Copyright A. von Graevenitz., 2015

Licensee PAGEPress, Italy

Infectious Disease Reports 2015; 7:6103

doi:10.4081/idr.2015.6103

6. Shakoor S, Fasih N, Jabeen K, Jamil B. Rothia dentocariosa endocarditis with mitral valve prolapse: case report and brief review. Infection 2011;39:177-9.

7. van Scoy RE, Cohen SN, Geraci JE, Washington JA. Coryneform bacterial endocarditis. Mayo Clin Proc 1977;52:2169.

8. Belmares J, Detterline S, Pak JB, Parada JP. Corynebacterium endocarditis speciesspecific risk factors and outcomes. BMC Infect Dis 2007;7:4.

9. Gubler J, Huber-Schneider C, Gruner E, Altwegg M. An outbreak of nontoxigenic Corynebacterium diphtheriae infection: single bacterial clone causing invasive infection among Swiss drug users. Clin Infect Dis 1998;27:1295-8.

10. Muttaiyah S, Best EB, Freeman JT, et al. Corynebacterium diphtheriae endocarditis: a case series and review of the treatment approach. Int $\mathrm{J}$ Infect Dis 2011;15:e584-8.

11. Hirata Jr R, Pereira GA, Filarey AA, et al. Potential pathogenic role of aggregativeadhering Corynebacterium diphtheriae of different clonal groups in endocarditis. Braz J Med Biol Res 2008;41:986-91.

12. Morris A, Guild I. Endocarditis due to Corynebacterium Pseudodiphtheriticum: five case reports, review, and antibiotic susceptibilities of nine strains. Rev Infect Dis 1991;13:887-92.

13. Lee PP, Ferguson Jr DA, Sarubbi FA. Corynebacterium striatum: an underappreciated community and nosocomial pathogen. J Infection 2005;50:338-43.

14. Park HJ, Na S, Park SY, et al. Clinical significance of Propionibacterium acnes recovered from blood cultures: analysis of 
524 episodes. J Clin Microbiol 2011;49:1598-601.

15. Sohail MR, Gray AL, Baddour LM, et al. Infective
Propionibacterium species. Clin Microbiol Infect 2009;15:386-94.

16. Günthard H, Hany A, Turina M, Wüst J. Propionibacterium acnes as a cause of aggressive aortic valve endocarditis and importance of tissue grinding: case report and review. J Clin Microbiol 1994;32:30435 . 